\title{
Paleoearthquakes and slip rates of the North Tabriz Fault, NW Iran: preliminary results
}

\author{
Khaled Hessami $\left({ }^{1}\right)$, Daniela Pantosti $\left({ }^{2}\right)$, Hadi Tabassi $\left({ }^{1}\right)\left({ }^{3}\right)$, Esmael Shabanian $\left({ }^{1}\right)$, \\ Mohammad R. Abbassi $\left({ }^{1}\right)$, Khalil Feghhi $\left({ }^{1}\right)$ and Shahryar Solaymani $\left({ }^{1}\right)$ \\ $\left.{ }^{1}{ }^{1}\right)$ International Institute of Earthquake Engineering and Seismology (IIEES), Tehran, Iran \\ ${ }^{2}$ ) Istituto Nazionale di Geofisica e Vulcanologia, Sezione di Roma 1 - Sismologia e Tettonofisica, Roma, Italy \\ $\left(^{3}\right)$ Department of Geology, Islamic Azad University, Ashtian, Tehran, Iran
}

\begin{abstract}
The North Tabriz Fault is a major seismogenic fault in NW Iran. The last damaging earthquakes on this fault occurred in 1721, rupturing the southeastern fault segment, and in 1780 , rupturing the northwestern one. The understanding of the seismic behavior of this fault is critical for assessing the hazard in Tabriz, one of the major cities of Iran; the city suffered major damage in both the 1721 and 1780 events. Our study area is located on the northwestern fault segment, west of the city of Tabriz. We performed geomorphic and trenching investigations, which allowed us to recognize evidence for repeated faulting events since the Late Pleistocene. From the trenches, we found evidence for at least four events during the past $3.6 \mathrm{ka}$, the most recent one being the 1780 earthquake. On the basis of different approaches, horizontal slip per event and slip rates are found in the ranges of $4 \pm 0.5 \mathrm{~m}$ and 3.1-6.4 mm/yr, respectively. We also attempted an estimate of the average recurrence intervals which appears to be in the range 350-1430 years, with a mean recurrence interval of $821 \pm 176$ years. On the basis of these results, the northwestern segment of the North Tabriz Fault does not appear to present a major seismic potential for the near future, however, not enough is known about the southeastern segment of the fault to make a comparable conclusion.
\end{abstract}

Key words active tectonics - paleoseismology Iran Tabriz - earthquake

\section{Introduction}

NW Iran is a region of intense deformation and seismicity situated between two thrust belts of the Caucasus to the north and the Zagros Mountains to the south (fig. 1). Earthquake focal mechanisms suggest that the convergence between Arabia and Eurasia has been accommodated mainly through WNW-trending right-lat-

Mailing address: Dr. Khaled Hessami, International Institute of Earthquake Engineering and Seismology (IIEES), P.O. Box 19395/3913, Tehran, Iran; e-mail: khaled@dena.iiees.ac.ir eral strike-slip faults in this region (fig. 1; Jackson, 1992). These strike-slip faults appear to be the southeastern continuation into NW Iran of the North Anatolian Fault and other right-lateral faults in SE Turkey (Westaway, 1990, 1994; Jackson, 1992). However, right-lateral faulting in the SE Turkey-NW Iran region is not continuous but consists of several discontinuous fault segments (figs. 1 and 2a). Three of these segments ruptured during earthquakes in 1930, 1966 and 1976 (McKenzie, 1972; Toksöz et al., 1977; Jackson and McKenzie, 1984; Westaway, 1990; Jackson, 1992). The North Tabriz Fault Segment, however, was seismically inactive during the last two centuries. Among the many historical earthquakes that have occurred in the Tabriz region (e.g., the 858, 1042, 1273, 1304, $1550,1641,1717,1721,1780$ and 1786 earthquakes), the destructive earthquakes of 1042 


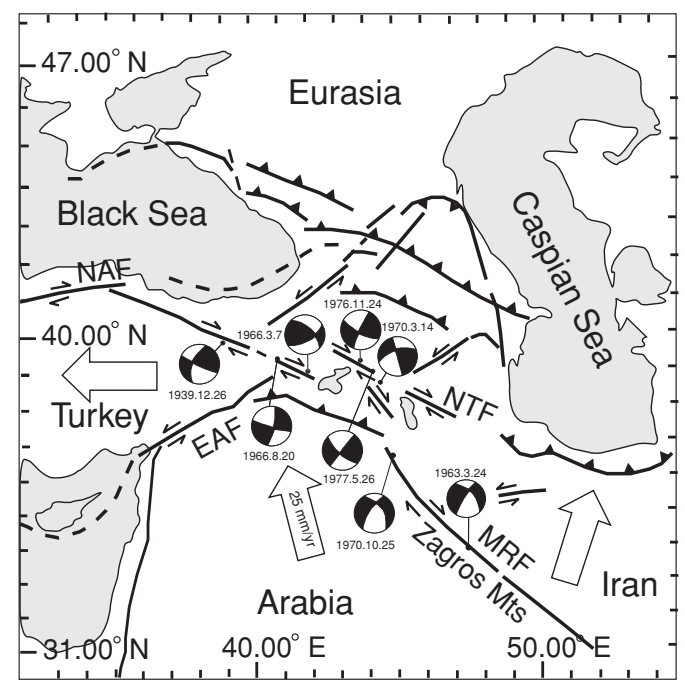

$\left(M_{s} 7.3\right), 1721\left(M_{s} 7.3\right)$ and $1780\left(M_{s} 7.4\right)$ were accompanied by coseismic surface faulting (Ambraseys and Melville, 1982; Berberian and Yeats, 1999). The 1721 and 1780 surface ruptures extended for at least 50 and $60 \mathrm{~km}$ long, respectively (fig. 2b; Ambraseys and Melville, 1982) and occurred 60 years apart in time on adjacent fault sections suggesting that large earthquakes along the North Tabriz Fault are

Fig. 1. Location map of the NW Iran-Eastern Turkey, adapted from Jackson (1992), with focal mechanisms of some of the large earthquakes $\left(m_{b}>5.3\right)$ in the Tabriz-Chaldiran seismogenic zone (Jackson and McKenzie, 1984). North Tabriz Fault (NTF), East Anatolian Fault (EAF), Main Recent Fault (MRF), North Anatolian Fault (NAF).
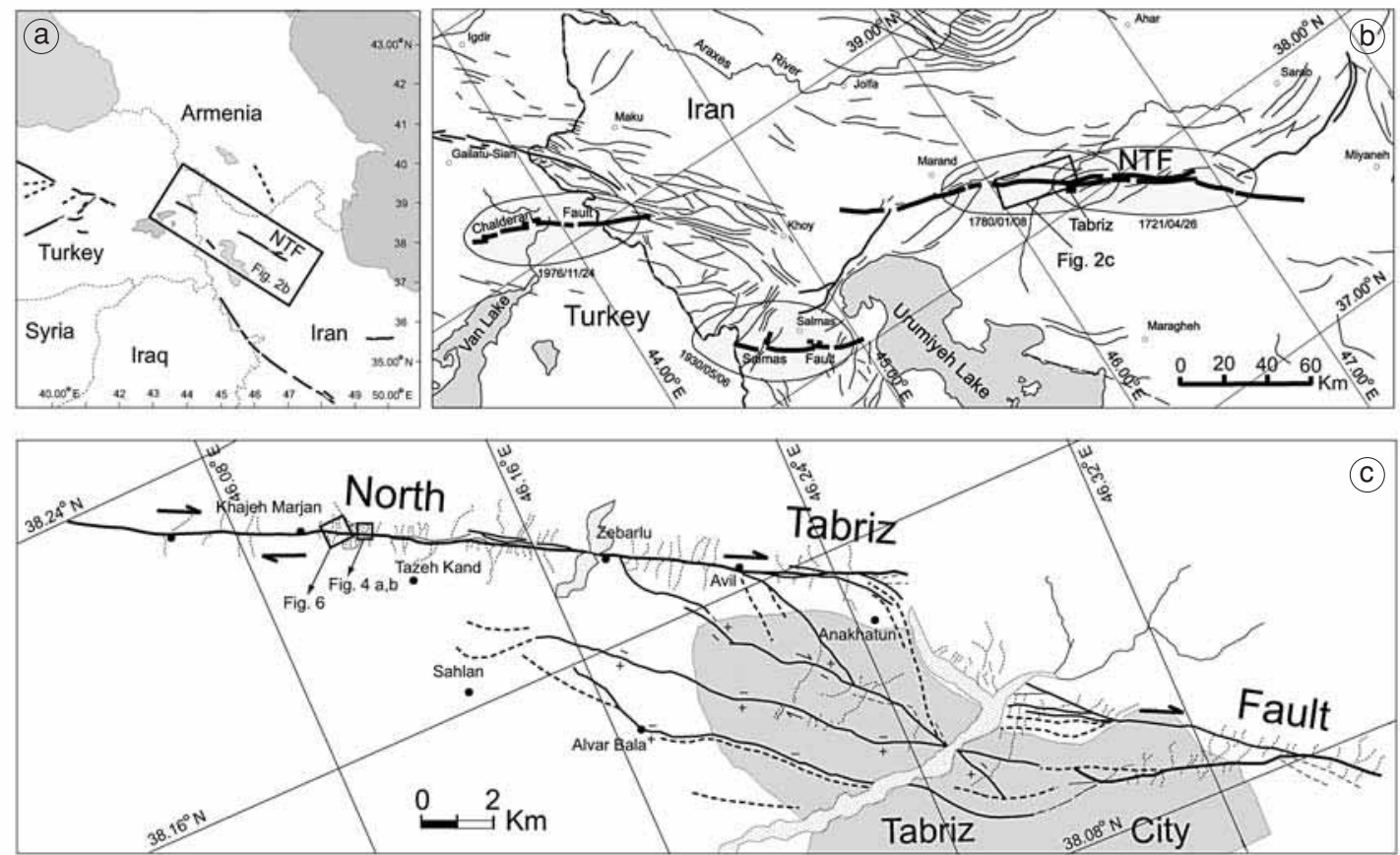

Fig. 2a-c. a) Small-scale regional map of active faults in NW Iran-Eastern Turkey (after Jackson and McKenzie, 1984). The rectangle encloses fig. 2b. b) Simplified map of the NTF and location of historical earthquakes, modified after Berberian (1997). Rectangle encloses fig. 2c. c) NW section of the North Tabriz Fault (after Karakhanian et al., 2001). Rectangles enclose figs. 4a,b and 6. 
clustered in time and are inter-related in space (Berberian and Yeats, 1999). The 1976 Chaldiran earthquake and its $55 \mathrm{~km}$ long surface rupture in Turkey (fig. 2a,b; Toksöz et al., 1977) suggest that there may be a typical surface rupture length for the most recent historical events in the Chaldiran-North Tabriz Fault System.

Total seismic moment release over 80 years implies that the coseismic deformation rate of about $20 \mathrm{~mm} / \mathrm{yr}$ (Jackson, 1992; fig. 1), contributed by strike-slip faults in the SE TurkeyNW Iran region, accounts for almost all the strike-slip component of $22 \mathrm{~mm} / \mathrm{yr}$ predicted by NUVEL 1 (DeMets et al., 1990).

This study describes the main geomorphic features and results of the first trench investigations conducted on a portion of the North Tabriz Fault that is supposed to have ruptured during the 1780 Tabriz earthquake (fig. 2b,c). Based on the results of radiometric dating and fault displacements during the late Holocene, the age of previous large events is estimated together with the possible slip per event and slip rates.

\section{The North Tabriz Fault}

The North Tabriz Fault (NTF) is one of the active faults in NW Iran that has a clear surface expression. It has an average strike of NW-SE over a length of about $150 \mathrm{~km}$ and appears to be generally close to vertical in dip. Right-lateral movement along this fault, documented by Berberian and Arshadi (1976) from study of aerial photographs, can also be seen clearly in the field (Karakhanian et al., 2001). Reporting right-lateral displacement of gullies for about $8 \mathrm{~m}$ during late Holocene, Karakhanian et al. (2001) suggest that the minimum slip rate along the NTF is about $2 \mathrm{~mm} / \mathrm{yr}$.

The 1780 earthquake ruptured the northwest part of the NTF, whereas the 1721 event ruptured the southeast part of the fault (fig. 2b; Ambraseys and Melville, 1982; Berberian and Yeats, 1999). We investigated the northwest part of the fault within the rupture zone of the 1780 earthquake, with particular attention to the fault in the vicinity of the city of Tabriz.

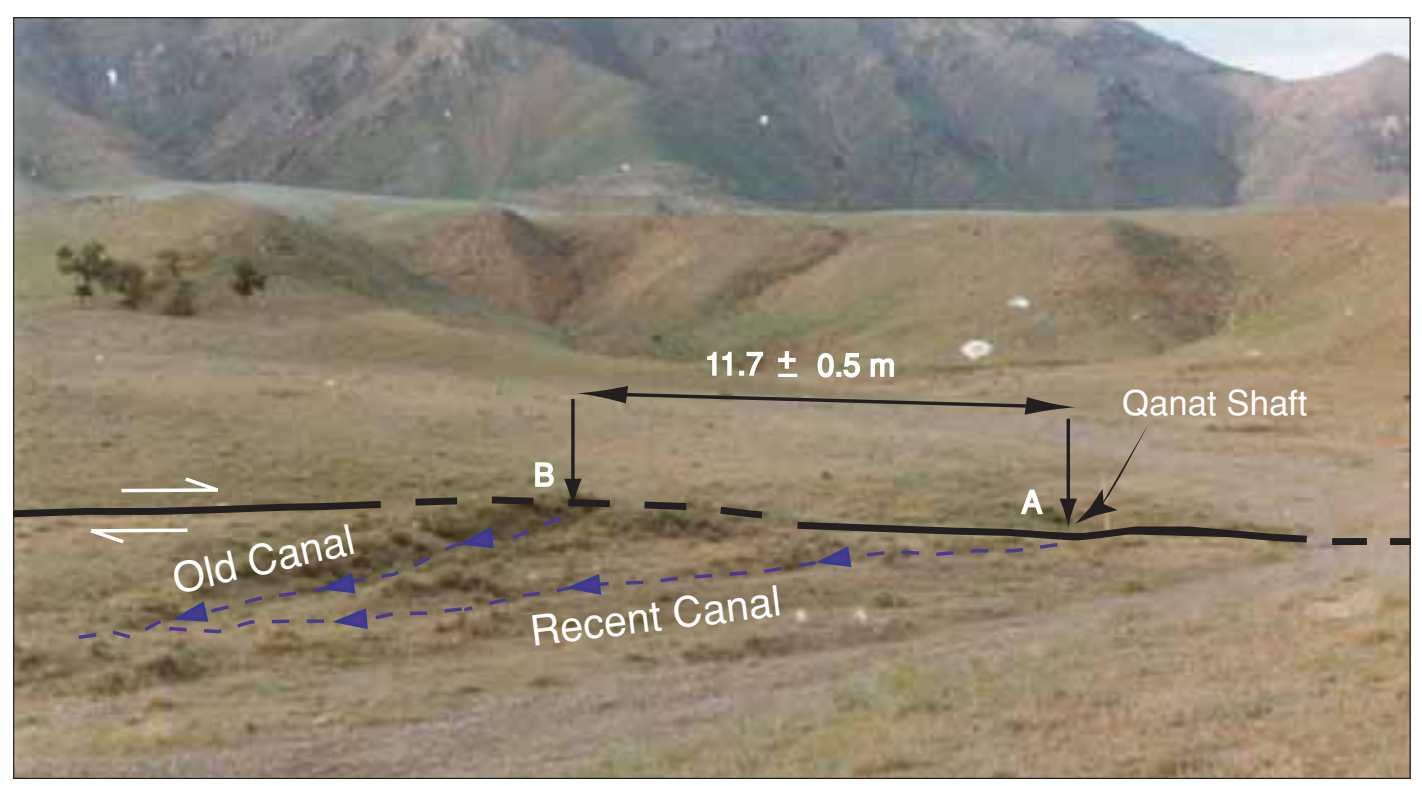

Fig. 3. Lateral offsets of the old canal across the North Tabriz Fault (looking north). The distance between old canal and its original position (i.e. the Qanat shaft) is $11.7 \mathrm{~m}$. The new canal is built where the old canal used to be. 

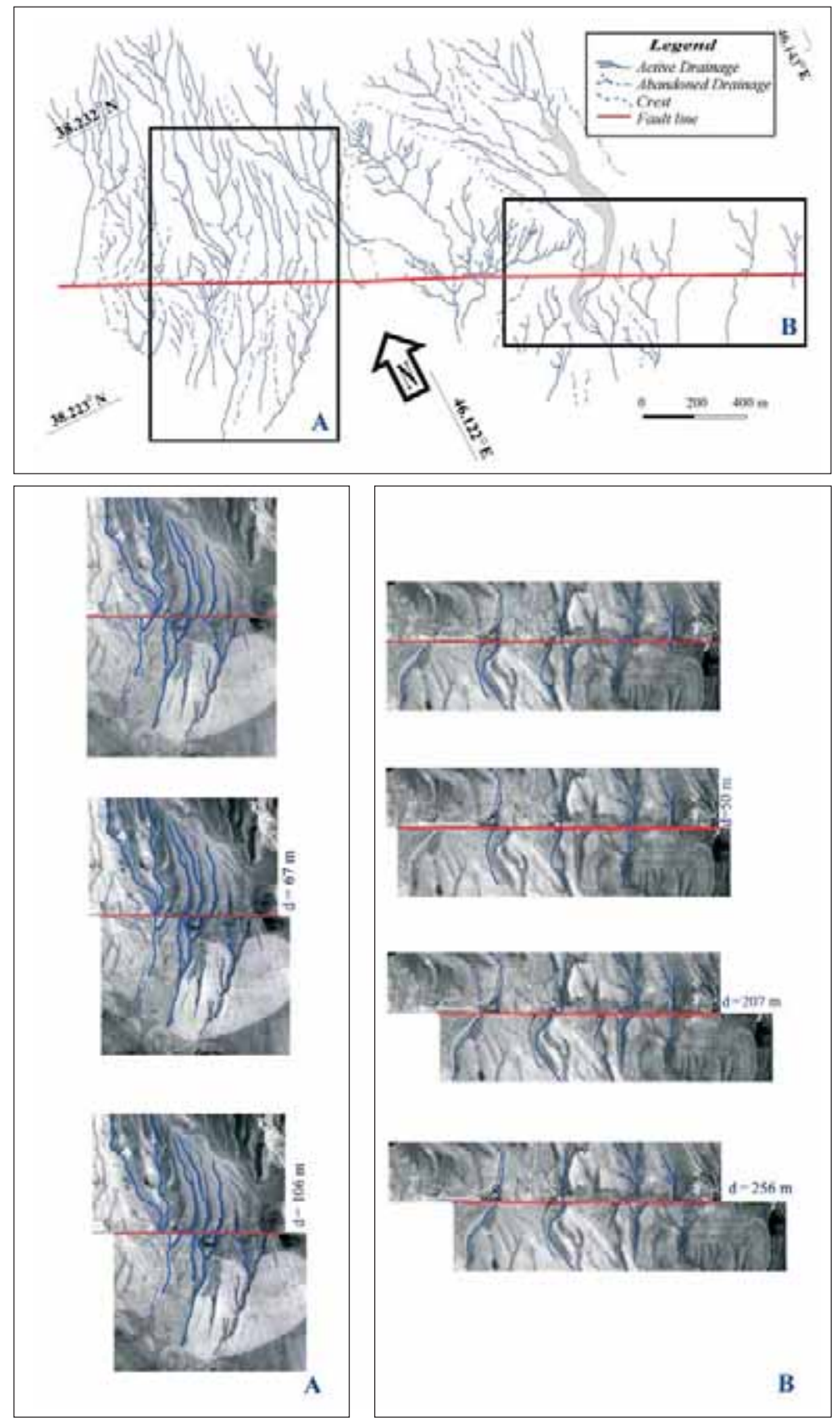

Fig. 4. Offsets of stream beds along the North Tabriz Fault. A and B show aerial photographs $(1: 10000)$ of cumulative right-lateral displacements along the NW section of the North Tabriz Fault. Top photographs in A and B represent present-day configuration of rivers and stream beds. Lateral offsets of the same geomorphic levels are recognized by reconstructing previous steps of deformation during the Late Pleistocene (top to bottom). 
The city is located in a pull-apart basin occurring between two major fault sections of the NTF arranged in an en échelon pattern, stepped right (fig. 2b,c; Karakhanian et al., 2001).

The fault section to the northwest shows clear geomorphic evidence for repeated surface faulting events (fig. 2c). This, and the fact that the fault crosses Late Pleistocene deposits, led us to start our investigation in this part of the fault. Here stream beds and gullies are systematically offset along the fault trace. The most spectacular feature among them is a line of Qanat (underground water tunnels, marked by lines of access shafts) displaced right-laterally (figs. 3 and 6).

At this locality, the new canal (A in fig. 3) was dug after the older canal (B in fig. 3) was offset right-laterally for about $11.7 \mathrm{~m} \pm 0.5$ (see fig. 6 for location). Offsets of several stream beds elsewhere along this section of the fault contain evidence for cumulative displacements by several individual offset events, however, these offsets are difficult to interpret. A maximum $256 \mathrm{~m}$ dextral offset can be measured by matching drainage systems (fig. 4). The vertical component of displacement varies from place to place between 2 and $11 \mathrm{~m}$, but in any case, the dip slip component is subsidiary to the main right-lateral strike-slip movement, or it may represent separation rather than slip. In fact, although it is the southern block which is downthrown relative to the northern side, the strike-slip movement along the fault has created scarps facing both north and south by shifting topography laterally in this relatively high-relief terrain.

\section{Trenches: stratigraphy, structure and paleoearthquakes}

In order to investigate the paleoearthquakes which occurred on this fault, we excavated two trenches $100 \mathrm{~m}$ apart perpendicular to the trace of that part of the fault that is supposed to have ruptured during the 1780 Tabriz earthquake. Trenches were also excavated parallel to the fault on either side at both locations (see figs. $2 \mathrm{c}$ and 6 for location).

\subsection{Trench 1}

Location of trench 1 was selected where an upstream reach was dammed by a shutter ridge across the fault zone. At this location, two apparently recent scarplets were also recognized (fig. 5). Because of logistical problems, the trench exposed the shorter of these fault scarps as a zone of shearing a few meters wide (figs. 5 and 7a). The lower Pleistocene deposits forming the shutter ridge to the south (unit 100) are juxtaposed across this fault zone against the upper Pleistocene-Holocene deposits (Hossein-Khan-Nazer, 1999) of fluvial and debrisflow origin (units 107 to 118 in fig. 7a,c). The record of repeated dextral offset during multiple faulting events along this fault section is preserved in a sequence of scarp-derived deposits trapped into coseismically-formed depressions, referred to here as colluvial wedges. These colluvial wedges are mainly composed of coarse-grained sand, gravel, and angular pebbles within a sandy clay matrix. Individual colluvial wedges interpreted as evidence for individual earthquakes have been discriminated on the basis of their sedimentology and by using structural relations (fig. $7 \mathrm{a}, \mathrm{c}$ ). The bottom unit (101) of this sequence is severely deformed so that pebbles are sheared along fractures and are compacted in their matrix. A few fractures appear to be buried under this unit. The second unit (102) is compacted but is less deformed, with pebbles reoriented only within $10-20 \mathrm{~cm}$ of the fault plane. The third colluvial unit (103) is cut by only a few joints, but it clearly buries a fault. Unit 104 is mainly alluvium deposited over the youngest wedge of colluvium. All these units are bounded on their northern side by the fault zone which is overlain by the youngest stratigraphic unit (106) of fine-grained alluvial sand and silt. The presence of these alluvial deposits suggests that some erosion may have possibly occurred in the upper part of the section.

On the basis of this stratigraphic interpretation of colluvial wedges, we could speculate the occurrence of four events; however, for two of them we have also other independent evidence and thus, to be conservative, we consider only these of high reliability. Evidence for the oldest 


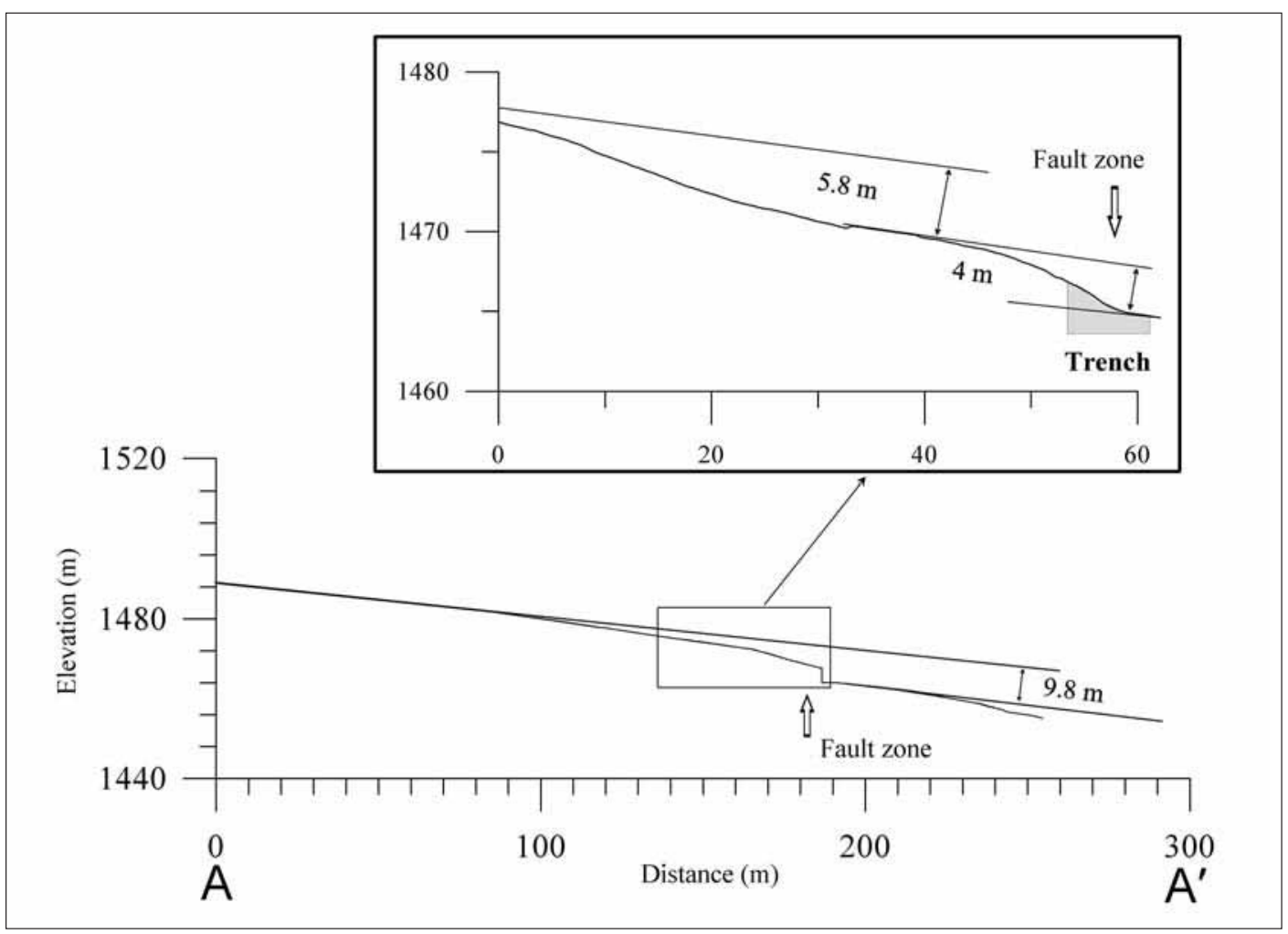

Fig. 5. Topographic profile across the fault trace near trench sites. This profile indicates a total vertical displacement of $9.8 \pm 0.3 \mathrm{~m}$ across two fault scarps. Trench 1 exposed the shorter of these fault scarps $(4 \mathrm{~m}$ high) as a zone of shearing a few meters wide.

Table I. Measured and dendrochronologically corrected ages of samples collected in the trenches 1 and 2. Measured ages have been corrected for $\mathrm{C}^{12} / \mathrm{C}^{13}$ in the laboratory and for $\mathrm{C}^{12} / \mathrm{C}^{14}$ by using the calibration program Oxcal v3.5 (Bronk Ramsey, 2000). For each sample a probability density is obtained. We report the $2 \sigma$ interval with the associated probabilities. For our study we took under consideration only the age intervals with probability above $10 \%$.

\begin{tabular}{ccccc}
\hline \hline Sample \# & Unit & Measured age BP & Cal age $2 \sigma$ & Probability $\%$ \\
\hline T2N02 & T2-? & $965 \pm 40$ & $990-1190$ A.D. & 95.4 \\
T2N03 & T2-204 & $1275 \pm 40$ & $660-870$ A.D. & 95.4 \\
T2N01 & T2-? & $1020 \pm 40$ & $890-830$ A.D. & 5.2 \\
& & & $950-1070$ A.D. & 74.8 \\
& & & $1080-1160$ A.D. & 15.4 \\
\hline T1N02 & T1-102 & $1915 \pm 40$ & 0-220 A.D. & 95.4 \\
T1N03LOW & T1-103 & $1510 \pm 40$ & $430-640$ A.D. & 95.4 \\
T1N03UP & T1-103 & $1230 \pm 70$ & $660-970$ A.D. & 95.4 \\
T1N01 & T1-101 & $3240 \pm 40$ & $1620-1410$ B.C. & 95.4 \\
T1N04 & T1-104 & $740 \pm 50$ & $1190-1320$ A.D. & 86.7 \\
\end{tabular}


Table II. Ages of paleoearthquakes as constrained in the trenches.

\begin{tabular}{cccc}
\hline \hline Trench 1 & & & \\
Event \# & Max age & Min age & Samples used \\
\hline T1-C & 1190 A.D. & 1780 A.D. & T1N04, historical considerations \\
T1-L? & 660 A.D. & 1320 A.D. & T1N03UP, T1N04 \\
T1-A & 0 A.D. & 640 A.D. & T1N03DOWN, T1N02 \\
T1-M? & 1620 B.C. & 220 A.D. & T1N02, T1N01 \\
T1-D & Not available & 1410 B.C. & T1N01 \\
T1-B & No age constraints & - & - \\
\hline Trench 2 & & & Samples used \\
Event \# & Max age & Min age & T2N04, historical considerations \\
\hline TR2-X & 990 A.D. & 1780 A.D. & - \\
TR2-W & 660 A.D.? & 1160 A.D. & T2N01, T2N03 assuming 204 was offset also by this event \\
TR2-Z & Not available & Not available & - \\
TR2-K & Not available & Not available & \\
\hline
\end{tabular}

event (event T1-D) is marked by the oldest of these colluvial wedges (unit 101) which accumulated in the area that sagged against the fault and overlies some fractures and faults in unit 101. The second event (uncertain T1-M?) could be located at the base of unit 102. The third event is well constrained (event T1-A) as it is marked by the upward termination of the south branch of the main fault at the base of unit 103 and by the deposition of unit 103 itself (fig. $7 \mathrm{a}, \mathrm{c})$. Unit 104 does not seem to record a distinct event of deformation but it may have occurred in a depression formed by a more recent event (event T1-L?). Finally, the main fault branch appears clearly capped by the alluvium of unit 106. This contact is clearly an erosional one, but it may represent the most recent event horizon in this trench (event T1-C). The lack of direct stratigraphic relations prevents us from understanding whether event T1-C coincides with T1L? or whether they are two independent events. Further evidence of older events in the trench section includes event T1-B at the top of unit 107.

The timing of these paleoearthquakes is poorly constrained by few radiocarbon dates on organic rich deposits as no charcoal was found (see table I and fig. 7a for sample age and location). At least four surface faulting events have occurred since $3.6 \mathrm{ka}$, the most recent one being younger than 1190 A.D. A summary of the age of the events is in table II.

\subsection{Trench 2}

Trench 2 was excavated across the fault scarp near a pond area on the side of a small erosional gully (figs. 6 and 7b). The trench exposes recent fluvial deposits which are mainly composed of fine-grained sand and silt within a clay matrix (units 200 to 221 in fig. $7 b$ ).

Deposits exposed in trench 2 have been intensely disrupted by north- and south-dipping, high-angle faults over a $15 \mathrm{~m}$ wide zone within which we distinguished two major zones of deformation, indicated as northern fault zone and southern fault zone (fig. 7b). The northern fault zone in trench 2 can be traced to the fault zone in trench 1 (fig. 6). Evidence for some small scarplets at the surface suggests Late Holocene faulting at this site (fig. 7b,d). However, all these scarplets could not be traced to the trench walls, probably due to bioturbation.

Truncation of fault splays by sedimentary units at different stratigraphical levels as well as scarp-derived colluvium is interpreted as evidence for the occurrence of at least four individual paleoearthquakes. The event horizons (i.e. the ground surface at the time of the faulting) for these paleoearthquakes are located in the following stratigraphic positions:

a) Event T2-X, top of unit 204 or middle portion of unit 208 as suggested by some open fissures in-filled with unit 208 and fault splays 
apparently truncated by the upper part of unit 208 (if this latter is not an effect of bioturbation). The vertical displacement of unit 204 could be attributed to horizontal juxtaposition of this unit with irregular thickness along the strike-slip fault, but it can also suggest evidence for further events.

b) Event T2-W, top of unit 210, where fault splays are truncated by unit 211 (at $5 \mathrm{~m}$ ). Evidence for this event possibly exists also between 0 and $1 \mathrm{~m}$ where some of the open fissures, in-filled by unit 206, are not aligned with the most recent ones. This suggests the occurrence of surface faulting just after or during deposition of unit 206.

c) Event T2-Z, base of unit 213, where fault splays terminate and are buried by unit 213 at 10 -
$11 \mathrm{~m}$ and 15-16 $\mathrm{m}$. This event may coincide with event T2-W, however, the lack of direct stratigraphic relations does not allow us to confirm this hypothesis.

d) Event(s) T2-K, at the top of unit 200, three channel fills are stacked onto the southern fault zone (at 10-16 m) and cap several fault traces.

The timing of only two of these paleoearthquakes is constrained by radiocarbon dates on organic rich deposits as no charcoal was found elsewhere (see table I and fig. 7b for sample age and location). The most recent event is younger than 990 A.D., whereas the penultimate event may be constrained between 660 and 1160 A.D. A summary of the age of the events is in table II.

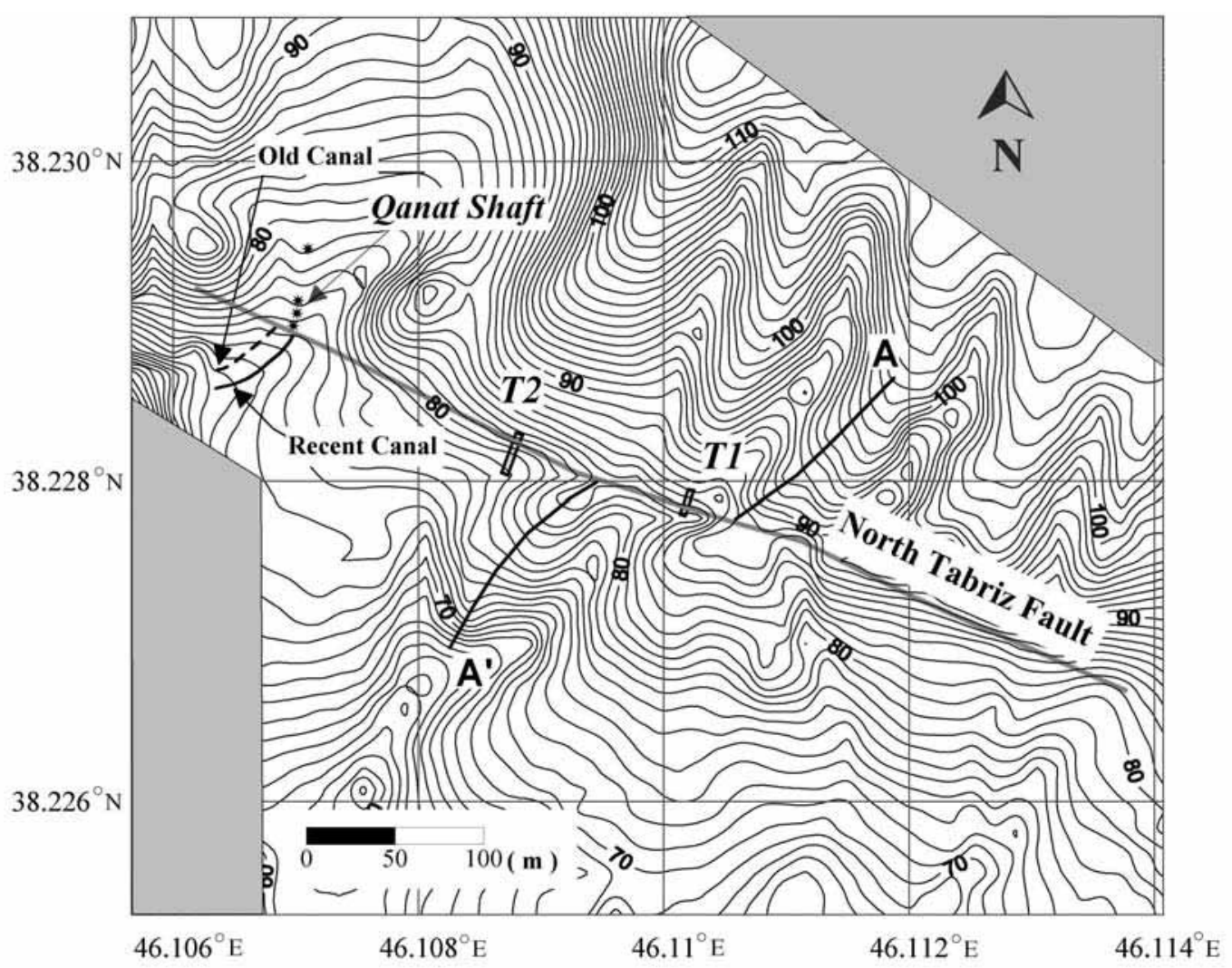

Fig. 6. Large scale topography map ( $1 \mathrm{~m}$ contour line) of the study area and location of trenches (T1 and T2) based on 1075 measured points using Total Station equipment. Displacement of Qanat shaft can be seen on either side of the fault trace. A-A' shows location of topographic profile in fig. 5. Double lines show trench locations. 

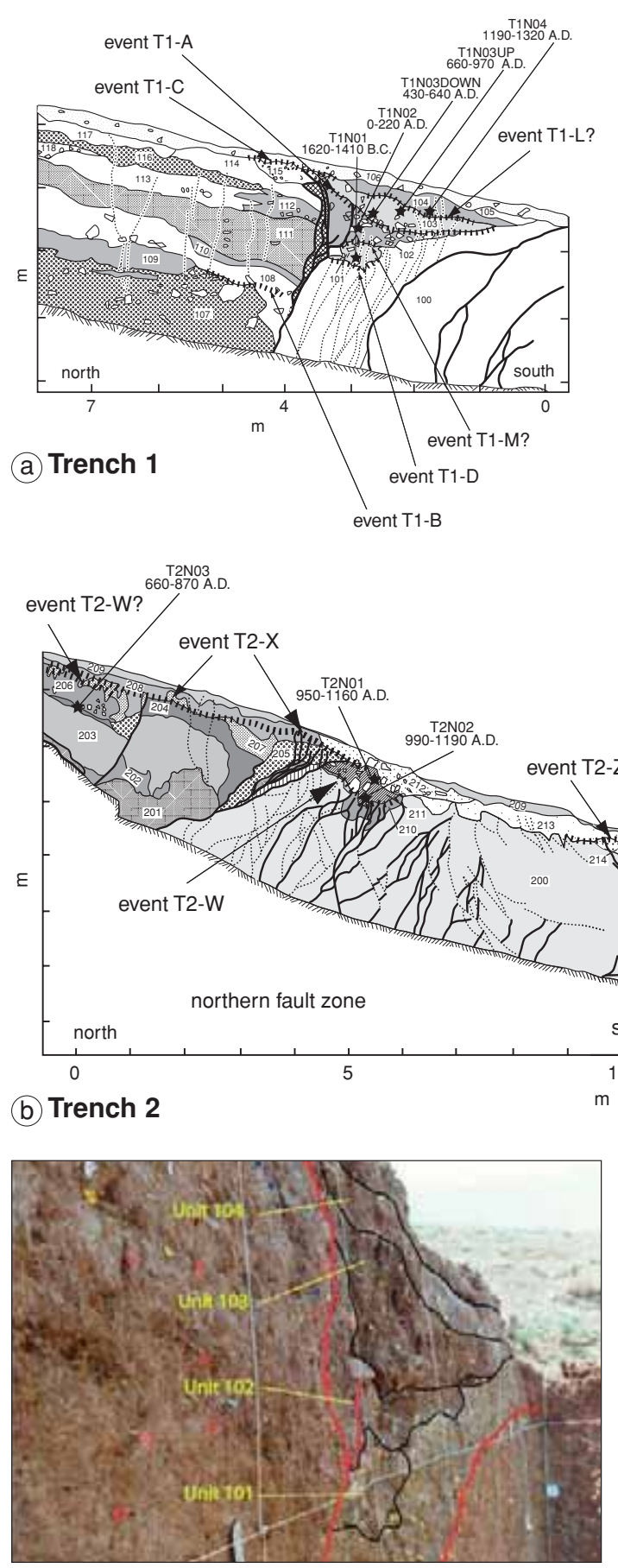

(C)
Fig. 7a-d. Trench logs along the North Tabriz Fault west of Tabriz city. a) Simplified $\log$ of trench 1 based on 1:20 field mapping. Trench 1 exposed Upper Pleistocene-Holocene deposits of fluvial (units 107-118) and debris flow-colluvial (units 101-104) origin. These are mainly composed of coarse-grained sand, gravel, and angular pebbles within a sandy clay matrix. b) Simplified log of trench 2 based on 1:20 field mapping. Trench 2 exposed Upper PleistoceneHolocene deposits of fluvial origin (all units aside from units 211 and 212) which are mainly composed of fine-grained sand and silt within a clay matrix. Units 211 and 212 are mainly of debris flow origin. c) Detail of the fault zone of trench 1, east wall, looking south. d) View of the northern fault zone of trench 2. Notice the small scarplets at the surface on top of the fault zone.

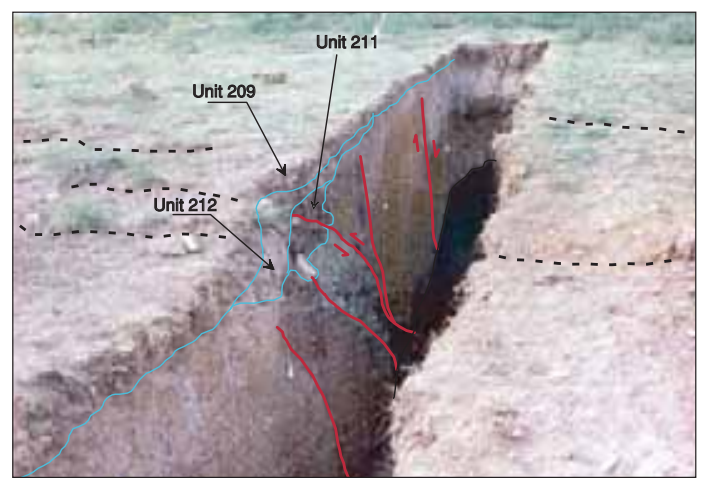

(d) 


\section{Coseismic slip, slip rates and recurrence intervals}

\subsection{Slip per event}

Unfortunately no direct information about the horizontal movement during each of the surface faulting events recognized in trenches 1 and 2 could be retrieved from the fault-parallel excavations (fig. 6). From the trenches, only rough estimates of the amount of individual vertical displacements can be obtained. These are based only on the thickness of the deposits interpreted as colluvial wedges, assuming that the vertical slip at the trench site reflects true slip on the fault and not lateral topographic juxtaposition. Selecting a crest of an interfluve on either side of the fault (marked $\mathrm{AA}^{\prime}$ on fig. 6), we avoided juxtaposition of topography along the topographic profile in fig. 5. Even taking into consideration these large uncertainties, we can obtain from trench 1 a thick- ness of colluvium that varies between 0.3 and 0.9 $\mathrm{m}$ that directly translate to minimum vertical coseismic slip.

An estimate of the horizontal coseismic slip can be obtained by measuring the right-lateral offset of modern stream channels measured along the strike of the North Tabriz Fault in the study area. A frequency histogram of lateral offsets over $2.5 \mathrm{~km}$ distance along the fault trace is provided in fig. 8 to identify peaks, which could represent the amount of offset related to one or more individual paleoearthquakes. Figure 8 shows several peaks indicating that the cumulative slip of offset channels could be associated with individual increments of $3.5-4.5 \mathrm{~m}$. This figure could thus represent the coseismic offset produced by the most recent earthquake and also the typical offset for this section of the North Tabriz Fault. However, even if we consider it dubious, we cannot exclude the possibility that the $4 \pm 0.5 \mathrm{~m}$ offset increments may have been produced by more than one earthquake.

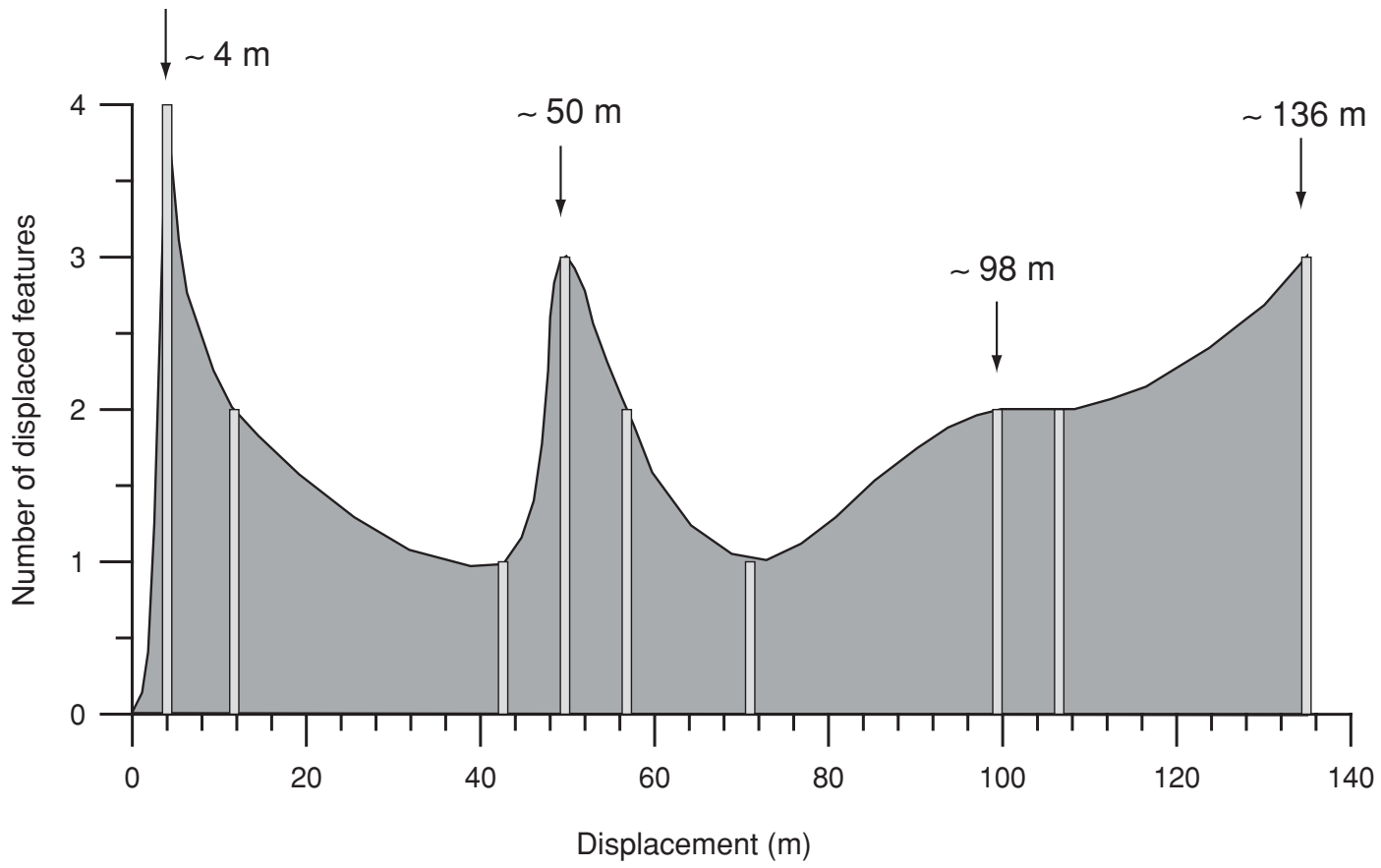

Fig. 8. Frequency histogram of lateral offsets (represented as Gaussian probability density functions) over 2.5 $\mathrm{km}$ distance along northwestern section of the North Tabriz Fault. Several peaks indicate the cumulative slip of offset channels could be associated with individual increments of 3.5-4.5 m. 


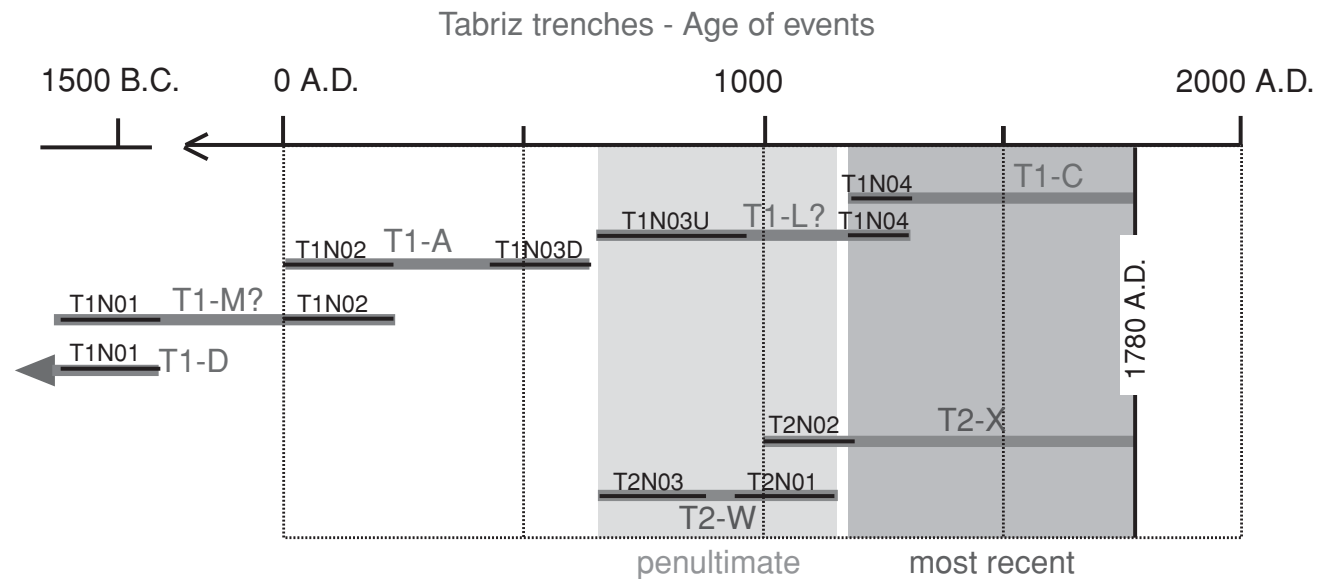

Fig. 9. Attempt of correlation of paleoearthquakes between the two trenches. Black bars are the age ranges of the samples used to constrain the age of occurrence of paleoearthquakes which are reported as thick gray bars. Sample names and event names are shown too. Gray boxes show the correlated age of the most recent and penultimate events. On the basis of historical considerations we assume the most recent earthquake be the 1780 one.

\subsection{Slip rate}

The only direct estimate of the horizontal slip rate along this section of the North Tabriz Fault is based on the offset Qanats (figs. 3 and 6). The maximum age of the Qanat line is 3000 years (Forbes, 1964; Goblot, 1979; Kamiar, 1983; Potts, 1990); because it is horizontally offset for $11.7 \pm 0.5 \mathrm{~m}$, it implies a minimum horizontal slip rate of $3.7-4.0 \mathrm{~mm} / \mathrm{yr}$.

The ages of the offset drainages are not known, but by making some assumptions on the maximum age of the incised surfaces, we can compare long-term slip rates to the slip rate obtained for the past $3 \mathrm{ka}$. Channels incised within the Upper Pleistocene (maximum $125 \mathrm{ka}$ ) sediments (Hossein-Khan-Nazer, 1999) are right-laterally offset for about $250 \mathrm{~m}$, indicating a minimum slip rate of about $2 \mathrm{~mm} / \mathrm{yr}$.

On the other hand, young alluvial fans, incised by drainages that show a $67 \pm 10 \mathrm{~m}$ horizontal offset (fig. 4) and a $9.8 \pm 0.3 \mathrm{~m}$ vertical displacement (fig. 5) could be attributed to the last important post-glacial deposition following the last glacial peak (18 to $10 \mathrm{ka}$; Pedrami, 1987). If this assumption is correct, the minimum horizontal slip rate is 3.1-6.4 mm/yr, consistent with that obtained from the Qanats. On the same age assumption, the total vertical displacement of the same surface indicates a vertical slip rate of 0.5$0.8 \mathrm{~mm} / \mathrm{yr}$.

\subsection{Recurrence intervals}

Based on the chronological constraints in each trench for the occurrence of the paleoearthquakes, we attempted a correlation of events between the two trenches (fig. 9). At least four earthquakes occurred during the past $3.6 \mathrm{ka}$. The most recent event is younger than 990 A.D. in both trenches. Since the historical reports indicate that the 1780 earthquake ruptured this section of the fault (Ambraseys and Melville, 1982; Berberian and Yeats, 1999), we assume that the most recent event recorded in the trenches is the 1780 earthquake. The ages of the other events fall in very wide ranges because of the limited amount of dateable material found in the trenches. Even with these high uncertainties we can infer that the penultimate event occurred $910 \pm 250$ A.D., the third event back $320 \pm 320$ A.D., and the oldest one $700 \pm 920$ B.C. Comparing these ages with the historical record, the 1042 earthquake falls in 
the age interval of the penultimate surface faulting event found in the trenches. Although information on this event is mostly derived from the city of Tabriz, and thus it is hard to define the earthquake source only on the basis of felt reports, surface faulting is reported and certainly support the hypothesis that the 1042 earthquake ruptured at our trench site. No evidence for the other events which produced damage in Tabriz is found in the trenches. This may be due to different reasons: a) events were too small to produce surface faulting at the trench site; b) events occurred on different faults but this cannot be verified because of the limited historical information on the damaged area, c) mimicking of the geological evidence for these events occurred by more recent and larger earthquakes. On the basis of these ages an average recurrence interval for surface faulting events of ca. 350 to 1430 years and also a mean recurrence interval of $821 \pm 176$ years can be estimated.

Average recurrence interval estimates can also be obtained based on the number of events that contributed to displace a given anthropic/ geomorphic elements and their ages. By using the maximum 3000 years old Qanat (Forbes, 1964; Goblot, 1979; Kamiar, 1983; Potts, 1990) displaced $11.7 \pm 0.5 \mathrm{~m}$ and the $4 \pm 0.5 \mathrm{~m}$ slip per event, we can infer that at least 3 events contributed to its displacement. This would convert to an average recurrence interval of $c a .1000$ years. On the other hand, comparing the individual offset of $4 \pm 0.5 \mathrm{~m}$ with the $67 \pm 10 \mathrm{~m}$ long term displacements recorded by the $12-18$ ka surface, we can infer that 12 to 22 events contributed to the lateral offset of the drainages. This translates to average recurrence intervals ranging between 545 and 1800 years, in good agreement with the observations derived from the Qanat and trenches.

\section{Conclusions}

Geomorphic features and trenches opened west of Tabriz city show evidence for repeated surface faulting along this section of the North Tabriz Fault. At least four surface faulting events have been recognized during the past 3.6 ka. Because of the lack of datable materials, ages of events are poorly constrained, and cor- relation between the two trenches is difficult. However, taking into consideration these intrinsic uncertainties, we defined as much as we could the age of these events as 1780 A.D., $910 \pm 250$ A.D., $320 \pm 320$ A.D., and $700 \pm 920$ B.C. (see table II and fig. 9). Slip per event is estimated as $4 \pm 0.5 \mathrm{~m}$ horizontal and minimum $0.6 \pm 0.3 \mathrm{~m}$ vertical although this latter may not be truly representative of slip on the fault. Horizontal slip rates of 3.7-4.0 and 3.1-6.4 mm/yr are obtained on the basis of faulted anthropic features and on offset drainages, respectively. On a similar basis, vertical slip rates may be of the order of $0.5-0.8 \mathrm{~mm} / \mathrm{yr}$. Finally, average recurrence intervals calculated following different reasoning lines are as small as 350 years and as large as 1430 years. Our results show that large earthquakes $(M>7)$ on the NW segment of the North Tabriz Fault occur each 821 years (mean time) which is consistent with historical data.

Since this section of the North Tabriz Fault has not produced any major destructive earthquakes with surface faulting since 1780 (the past 220 years), assuming a constant slip rate accumulation and a characteristic slip per event at least $0.7-1.4 \mathrm{~m}$ of strain must have been accumulated along the northwest part of the NTF. This would suggest the potential of this part of the fault is not critical for the next few centuries, however, the possibility of smaller ruptures and clustering with periods of more frequent moderate earthquakes along the fault, should be considered.

Although this paper contains a preliminary understanding of the seismic behavior of this fault, important issues that have a critical importance for the highly populated city of Tabriz remain open such as the segmentation of the North Tabriz Fault Zone, the possibility that the fault ruptures also during earthquakes smaller than the 1780 one, the significance of the historical earthquakes not found in the trenches, and the existence of other sources in the area.

\section{Acknowledgements}

We thank Dr. C.J. Talbot for constructive comments and suggestions for improvements on an early draft of this work. We wish to thank 
Drs. R.S. Yeats and M. Berberian for their constructive reviews that substantially improved the original manuscript. We also thank M.J. Bolourchi and F. Ansari-Moghadam for help in logging the trenches. We appreciate field support provided by the International Institute of Earthquake Engineering and Seismology (IIEES), Tehran, Iran. This work was supported by the National Research Council, number 5006.

\section{REFERENCES}

Ambraseys, N.N. and C.P. Melville (1982): A History of Persian Earthquakes (Cambridge University Press, Cambridge), pp. 236.

BERBERIAN, M. (1997): Seismic sources of the Transcaucasian historical earthquakes, in Historical and Prehistorical Earthquakes in the Caucasus, edited by D. Giardini and S. Balassanian (Kluwer Academic Press, The Netherlands), NATO Asi Series, Serie 2: Environment, vol. 28, 233-311.

Berberian, M. and S. ArShadi (1976): On the evidence of the youngest activity of the North Tabriz Fault and the seismicity of Tabriz city, Geol. Surv. Iran Rep., 39, 397-418.

BERBERIAN, M. and R.S. YeATs (1999): Patterns of historical earthquake rupture in the Iranian plateau, Bull. Seismol. Soc. Am., 89, 120-139.

Bronk Ramsey, C. (2000): OxCal Program v3.5, University of Oxford Radiocarbon, Accelerator Unit (http:// www.rlaha.ox.ac.uk/oxcal/oxcal.htm).

DeMets, C., R.G. Gordon, D.F. Argus and S. Stein (1990): Current plate motions, Geophys. J. Int., 101 425-478.
Forbes, R.J. (1964): Studies in Ancient Technology (Leiden, Netherlands: E.J. Brill), vol. 1, pp. 205.

Goblot, H. (1979): Les Oanats: une Technique d'Acquisition de l'Eau (Paris, Mouton), pp. 236.

JACKSON, J. (1992): Partitioning of strike-slip and convergent motion between Eurasia and Arabia in Eastern Turkey and the Caucasus, J. Geophys. Res., 97, 12471-12479.

JACKSON, J. and D.P. MCKENZIE (1984): Active tectonics of Alpine-Himalayan belt between Western Turkey and Pakistan, Geophys. J. R. Astron. Soc., 77, 185-264.

HosseIN-KHAN-NAZER, N. (1999): Geomorphological map of Sardrud, Geol. Surv. Iran Rep., sheet 5266 III, series K753.

KAMIAR, M. (1983): The Qanat system in Iran, Ekistics, 50, 467-472.

Karakhanian, A.S., V.G. Trifonov, H. Philip, A. Avagyan, K. Hessami, F. Jamali, M.S. BayRaKtutan, H. BagdassaRIAN, S. ARAKELIAN and V. DAVTIAN (2001): Active faulting and natural hazards in Armenia, Eastern Turkey and NorthWestern Iran, Tectonophysics (in press).

McKenZIE, D.P. (1972): Active tectonics of the Mediterranean region. Geophys. J. R. Astron. Soc., 30, 109-185.

Pedrami, M. (1987): Quaternary stratigraphy of Iran, Geol. Surv. Iran Rep., serial n. 551.79 (55) Pe [in Farsi].

PotTs, D.T. (1990): From prehistory to the fall of the Achaemenid Empire, in The Arabian Gulf in Antiquity (Oxford, Clarendon Press), vol. 1, pp. 460.

Toksöz, M.N., E. Arpat and F. SAROGLu (1977): East Anatolian earthquake of 24 November 1976, Nature, 270, 134-150.

WestaWAy, R. (1990): Seismicity and tectonic deformation rate in Soviet Armenia: implications for local earthquake hazard and evolution of adjacent regions, Tectonics, 9, 477-503.

Westaway, R. (1994): Present-day kinematics of the Middle East and Eastern Mediterranean, J. Geophys. Res., 99, 12071-12090. 
